\title{
Lukman Al Hakim Messages: A Theoretical Model on How to Teach In Modern Era
}

\author{
Abdullah Katutu ${ }^{1}$ \\ Abur Hamdi Usman² \\ 'STAIN Watampone, Bone, South Sulawesi, Indonesia \\ 2International Islamic University College Selangor (KUIS), Malaysia \\ Corresponding Author Email: aburhamdi@kuis.edu.my
}

\section{Doi:10.5901/mjss.2015.v6n6s4p175}

\section{Abstract}

This study aimed to understand the purposes of fostering and education conducted by Lukman al Hakim, to describe the methods used by Lukman al-Hakim in educating their children, to determine the level of implementation of educative values from the story of Lukman al Hakim to the modern education. This paper conducted a small research in the literatures related to the purpose of research, to explore several idea of teaching model to be applied in contemporary era. Hence, Lukman al Hakim's messages as necessity of educational methodology such as: educating through practice and action, coaching through attention or supervision, guiding through advisory lesson and training with punishment.

Keywords: education; Lukman al Hakim; practice; coaching; punishment; advisory.

\section{Who is Lukman Al Hakim?}

For most Muslims, figure Lukman al Hakim would have been quite familiar. Considering preachers and teachers always make him as an exemplary figure of parenting parents in guiding their children. However, there might be among us wondering whether he was one of Prophet or a wise man in living his life, or probably he was merely only a symbolic verse written in the Qur'an for caliph to delivered particular messages on earth. Those Opinions indeed are still discourse. Here, this paper tries to argue some expert opinions about Lukman al-Hakim. According to Ahmad Mustafa al-Maraghi (1946) in his exegetical book, Lukman al-Hakim was a carpenter with black skin, Egyptians who lived completely simple. However, Allah had given wisdom and prophetic confers to him. Al-Maraghi's opinion was also supported by Ikrimah. According to Ikrimah, Lukman al Hakim was a prophet, a wise man (al-Hakim). In the book of al-Ghayts Qathr also said that among the prophets and apostles who have been mentioned in the Qur'an, there was numerous prophet as yet unnamed so that there is possibility of Lukman al Hakim was one of between them. According to Ibn Abbas, Lukman alHakim was a slave of Habasyiyah (Ethiopia), most likely he was Aesopus, because words of wisdom. Aesopus was quite similar with Lukman al-Hakim wise words. Aesopus was a slave and black as well, which according to Winkler Prins Encyclopaedie he lived around 550-SM. Again, according to Khalid al-Rab'l, Lukman al Hakim was a slave and a carpenter from Habsy.

According to al-Baidhawi (2003) in his commentary entitled Tafsir al-Baidhawi which mentioned Lukman was one of a son of Azar, a cousin of the Prophet Ayyub. He lived during the Prophet Dawud era and ever became a mufti before the coming of the Prophet Dawud as apostles. Furthermore, al-Baidhawi mention based on the opinion of majority scholars that Lukman was not a prophet but only a judge. Inline with Baidhawi, Wahbah al-Zuhaili (1991) also said in Tafseer al-Munir that Lukman was one of Azar's children, a cousin of the Prophet Ayyub with black skin from SudanEgypt, lived in the same periode of time of the Prophet Dawud as, and then Lukman studied to him.

\section{What can we Learn from Lukman Al Hakim's Messages?}

In the Islamic view, education is primary in forming the morality of human. Islamic Education should develop all aspects of human life, spiritual and intellectual, individuals and groups, and encourage all these aspects towards the attainment of perfection of life. Departing from this issue, Islamic education is considered "failed" in achieving educational goals, it is necessary to reformulation Islamic education through caring and guidance to the child in the more humane family. This assert that the Lukman al Hakim's messages as educational methodology is necessary, to be considered influential in contemporary educating, as follow: 


\subsection{The Role of Educational Model}

Modeling in education is a great influential method and proved most successful in preparing and shaping the moral aspects, spiritual and social ethos for children (Daulay, 2004). This is because educator is best figure in the children's gaze, any of actions or habits, consciously or unconsciously, will be imitated by children.

Basically, human needs a figure to be a role model because it is human nature that tends to imitate others. Impersonation derived from a person's mental which he/she always feels that he/she is in the same feeling with other group member so that in this imitation, children tend to imitate adults. In essence, the impersonation is centered on three elements:

First, the pleasure to imitates and follow other. Children courage by a vague desires that unconciously lead them duplicate of those they admire. In this case the Qur'an has given a warning to parents, especially fathers to always strive to maintain warmth, affection, and potition as a role model for their children.

The Second, readiness to replicate. Usually replicating process starts when human experiencing various crises, social problem and others. From this, human will search for a role model or a leader who throughout his behavior will be imitated. Weak human condition can be brought on impersonation of the stronger parties thus the child will replicate his/her father (Salthut, 1998).

Third, every impersonation sometimes has a purpose that is already known by the impersonator or could be also does not clear or even none. Basically among children, impersonation is more likely driven by the goal of devenitive life, where tendency to maintain individual life as if they were in the shadow of the strong and powerful individuals, which makes weak people duplicate. From this impersonation, they felt the strength and courage. This imersonation activity will increase to be thinking level that combines awareness activities, linkages imitation and pride feeling if the development of consciousness in their impersonation increased. In Islamic education, this conscious imitation increased to following (ittiba) that these kind will continue to grow when accompanied by instructions or knowledge of the purpose and how to impersonate (al-Nahlawi, 1983). Through the Islamic concept of imitation, children will understand that imitate and follow the path of the leaders invited to obedience to God.

\subsection{Educating through practice and action}

Fundamentally, if educating is done through practice or direct application will familiarize special impression for children so that the robustness of science in the life of children more secure. However, application of science supports the truth of science itself as well as deciding on the acceptance of science seeker on the side of God. This objective will become a picture for children to understand the problems more details, deeper impact, and more benefits for life.

The above capture, warned that an educator in this case parents and teachers should direct the children to determinate the will to apply knowledge they received to their individual and social life as well. Parents and teachers are required to monitor their children continuously and repeatedly.

\subsection{Educating through attention or supervision}

Educating with attention is devote, pay attention and always follow child's development in coaching faith and moral, spiritual and social preparation, besides always ask about the situation of physical education and scientific capabilities (Ulwan, 1981). A must pay attention to and supervise the child, has spoken by God:

"O you who have believed, protect yourselves and your families from a Fire....." (QS.66:6)

How come parents protect their families, and teachers maintain student from the fires of hell, if they do not govern and prohibit them, do not pay attention and do not control them.

\subsection{Educating through Advisory Lesson (Mau'idzah)}

In the dictionary of al-Muhith there is a word "wa'adzah, ya'idzuh, wa'idzah, wamau'idzah," which means reminded of something that can melt heart and that something can be as reward or the punishment, so they became remember. While the Tafsir al-Manar, when interpreting QS al-Baqarah / 2: 232, Sayyid Ridha said that al-Wa'dzu means of advice and warnings with goodness and can soften someone hearts and encourage to charity.

Based on the contemplation of al-Manar commentary on the Qur'an verses that contain the word wa'idza can be 
concluded that advice has several forms and concepts, and most importantly are provision of advice in the form of an explanation of truth and interests of something, with the goal of keeping people away from immorality so that able to can generate happiness and benefits. In the Qur'an, the word of advisement (nasihah) presented repeatedly by the Apostles when their verbal dialogue with their people, such as Hood said to his 'Ad in the QS al-A'raf / 7: 68

"I convey to you the messages of my lord, and I am to you a trustworthy adviser."

Those verses above show that the condition of advice are mandatory or delivery the truth of Islamic law, and unseen things as it is without changed or mixed with anything else. Similarly on QS Lukman / 31: 13-17 and also QS Saba '1 34: 46-47.

Warning in the sense that advisor should be spoken the concepts and warning into the memory of object advice. It has become a reality that sincere advices will trace and influence if it enters the peaceful soul, thinking and wiseful mind. The advice will get fast response and leave deep scars. The Qur'an has affirmed this notion in many verses, and repeatedly mentions the benefits of the warning in words that contain instructions and sincere advices: "Indeed in that is a reminder for whoever has a heart or who listens while he is present [in mind]" (QS.50:37)

And also:

"And remind, for indeed, the reminder benefits the believers." (QS.51:55)

\subsection{Educating with tarhib (punishment)}

Tarhib is a threat or intimidation through penalty caused by implementation of a sin, mistake, or deeds that God has forbidden (Al-Nahlawi, n.d.). In addition, for reason underestimate implementation of the obligations that has been commanded by Allah, as He said:

"Then, surely it is We who are most kknowing of those most worthy of burning therein. And ther is none of you exept he will come to it. This is upon your Lord and inevitability decreed. Then We will save those who feared Allah and leave the wrongdoers within it, on their knees." (QS.19:70-72)

\section{Development Objectives in Islamic Education to be Quoted in the Acts of Lukman al Hakim}

Based on humanity view, then the real purpose of Islamic education is to have a strong basis for the development of education based on humanity. This is because the Islamic education is the process of creation or designing human personality based on the humanitarian outlook.

This view provides an overview of range definition and the scope of underlying concept of Islamic educational purposes (Arifin, 1991), such follow:

- Islamic Education involves the creation of human nature factor, which is to become an obedient and faithful servant of Allah.

- Islamic Education regarding of role factors, human responsibility and human potential as well, as illustrated in al-basyar, al-ins, al-insan al-unas, al-nas, the sons of Adam, zurriyat Adam, and abd Allah al-nafs, al-'aql, alqalb and al-ruh (Karwadi, 2008).

With guidelines on the definition above, the objectives of Islamic education in outline is the conceptualization of human common functions as a servant of Allah in accordance with the nature of its creation (religious function, aspects of diversity) and his caliphs (existential function), as well as covering material and covers all basic human potential (nature) included in itself as al-basyar, al-insan al-unas, al-ins, the sons of Adam, dzurriyat Adam, as well as the human aspects that other as depicted in al-nafs, al-'aql, al-qalb, and al-ruh.

In general, the purpose of Islamic education is directed to the effort to guide and develop the human potential until they can expose themselves optimally in accordance with both factors above. Islamic education is a process to transform individual behavior in personal, society life and environment (al-Syaibany, 1986). Refer to al Attas who said education is a process of instilling something into human beings. In this answer 'a process of instilling' refers to the method and the system by which what is called 'education' is gradually imparted; 'something' refers to the content of what is instilled; and 'human beings' refers to the recipient of both the process and the content (al-Attas, 1977). But this goal hard to achieved in the short run, but requires process and phasing. This objective is simply used as a basis for formulating the Islamic educational objectives; to be obtained more concrete references on Islamic educational goals thus the differential translation can be arranged. 
It should be reiterated, that the achievement of this goal cannot be done all at once and simultaneously. However, this is can be done gradually and in some stages, with each stage and level has equal relational ties and linkages. It is also based on the view of humanity, where human beings were created by God did not completely finished at once, but human was born in "unfinished" condition. Therefore, physical-biological quality of human naturally must be developed gradually and keep it balanced.

Based on the concept of human (al-basyar), the formulation of Islamic educational goals requires effort to meet the primary biological needs of human being. Muslims need to have physically strong and healthy, especially relating to the purposes of Islamic preaching, defense and Islamic law enforcement. Seen from this perspective, the purpose of Islamic education ideally is healthy and physically strong Muslim.

Islamic Education system requires every Muslim is mentally healthy, because the essence of faith teachings is in the mental matter. Mental health is closely related to physical health. As if mental education becomes very important, then physical matter becomes very important anyway.

A healthy and strong physical also relates to other factor in an expectated perfect human being, which is control one of skill needed to meet the primary needs of human being, such as the needs for food, clothing, and shelter. This conception requires education target that focuses its attention on vocational education, in order to obtain great men as caliphs of Allah on earth, in the sense of rigid to live under their biological life in the universe.

In relation to the dimension or professional skills, Islamic education objectives are directed to guide and develop human potentials in accordance with their respective talents. It is expected they have the ability that will match with their talents so forth can be used to provide a sustaining life. Thus the purpose of Islamic education in this dimension is pointed to perform ability formation which based on faith and generate benefits to society in the end.

Based on the concept of al-insan and al-nafs which refers to total value of human being, in fact it has been implied on human that categorically can bu used as a reference in formulating Islamic educational goals. With the conception of human, in the Quran states that real human does not seen from the physical aspect at all that human was created from soil (indicating of lowly and weak), likely the creation of Adam, so that Allah command the angels and demons to bow down to Adam (QS 2: 34). However, this is based on the quality to simbolized the mastery of Adam to the objects as a symbol of intellectual quality or awareness of his world. This is the reason why human labelized in the best creation ( $f i$ ahsani taqwim).

It is understood, that the term of "the best creation", not only refers to biological-physiological perfection, such as posture, beauty and physical perfection or completeness human stature, but also personality include meaningful capabilities such intellectual, moral, and spiritual. This we can make it as ideal human prototype as the goal of education in Islamic perspective.

In such definition, the objectives of Islamic education are not just to pursuit biological-psychological perfection, but also moral and ethical sensitivity, sharpness of intellect, flexibility cultural vision, and spirituality closeness to the Almighty Allah. More broadly, as social being, humans are expected to be able to act in harmony in social life (Tafsir, 2010) and Daradjat, et.al. (1995).

The Qur'an also has hinted about the need for refinement of personality. That is the process by which people try to make changes and increase personality. And one of the ways that can be achieved through internalization of God attributes that accumulates in al-asma 'al-Husna (the 99 beautiful names of Allah) into human life. It means that by making the attributes of God as the source of inspiration to colouring our personality development.

Humans are expected to take God as a prototype, and realize the character of God in life. It can be understood from the concept of al-ruh, that human is a creature that has potential of divine (ilahiyah).

Human does not possible to match and resemble the attributes of God. However, as God creatures with limitation, by putting God as prototype, people will always look for and try to direct his life on the pattern of ideal goal. Thus the meaningfulness of human life through the process of actualizing itself can be realized. Therefore, the whole process of personality development and balances as the objectives of Islamic education are not just an abstract concept, but finding a concrete pattern and significance in human's lives. In the context of Islamic education, coherent and balanced personality would be achieved if the domains are met in a balanced as well, either cognitive domain, psychomotor, affective, or dominant biological-physiological and mental-moral-spiritual.

In short, God's provisions regarding human qualities as mentioned above contain consequences of hope, during the journey of human's life must remain "fi ahsani Taqwim" and does not lead to "asfala safilin". Securing quality of "ahsani fi Taqwim" from all the distraction and destruction. While implementation can be done by making the attributes of God that are captured in "al-Asma al-Husna" as human prototype.

Based on the concept of al-nas and al-unas, the objectives of Islamic education is trying to guide and develop human potential optimally so that they can act in harmony with the demands and needs of the community environment. 
This conception requires further purpose of Islamic education which directed to the formation of social human who has righteous (taqwa) as the basis and nature of behavioral attitudes in social life. Human value in this context is the value of benefit. So that the human being as targeted objective in Islam is creating benefits to the surrounding.

Departing from this understanding, then the purpose of Islamic education put emphasis on efforts to guide and develop human potential in order to act in harmony in society, besides that expectation from the human role in the community life in line with God's command to be cautious person. Based on the concept of al-nas, the purpose of Islamic education is humanizing students to be able to participate in its status as social beings, Allah's servants ('abd Allah), as well as His caliph.

Based on the concepts of 'abd Allah and al-ins, then the purpose of Islamic education is aiming to the effort of establishment taqwa attitude. Therefore Islamic education efforts aimed at guiding and building human potential optimally in order to become a best servant of Allah i.e believes in the unseen, establish prayer, spend part of provision (rizq), faithful to the Quran, as well as to the judgement day. So that the indicators of success in achieving its intended destination is on the level of optimum observance of human that shown on the fulfillment of God's guidance.

Based on the concept of al-'aql and al-qalb, then Islamic edicational objective is intended for creation of human cognitive abilities, both intellectual and emotional intelligence. Intellectual characterized by the ownership of empirical knowledge, while emotional intelligence characterized by the ability to solve problems quickly and accurately.

In line with the concept, the objectives of Islamic education supposed to meet the following principles (Al Nahlawi, 1983):

- Intended to educate spiritual or human's heart. Spiritual means here is the human aspect in addition to physical and mind.

- Islamic educational goals should be load of guidance way of life. That is how humans can build well relation with Allah SWT, also with fellow humans, and with the surrounding environment.

- Islamic educational objective supposed to satisfy the curiosity aspect of human, besides as functional and practical consequences-pragmatic.

This formulation suggests that objectives of Islamic education are unified as a whole, which contain content objectives that integrated and comprehensive. It also summarized the purpose of human life in accordance with its duties, functions and also activities that are aligned with the demands of life as the expected results of education process. With the above guidelines, thus the objectives of Islamic education in outline is the conceptualization of general function of human being as a servant of God and His caliph on earth.

Education is a must for every human being because through education, people can be a real human being, whose personality has quality and integrity. The necessity of education for human is a reflection of human characteristics as homo educandum (Barsihannur, 2009). This means that people dynamically needs education. Good education process will produce significance growth and development of qualified human.

The Qur'an was revealed in order to elevate human dignity from lower scientific systems towards the advancement of modem science. History has proven that the era of pagan did not have direction and purpose in life, and then they have successfully brought by the Prophet Muhammad (pbuh) into better modern life, the lightful life with faith and respect for human dignity (Al-Munawar, 2005).

\section{Conclusion}

Thus it can be concluded that the purpose of education by Lukman al Hakim are: inclusive between faith, Islamic law and morals, integral and tiered between faith, Islam and ihsan, symbolically describes stability of relationship with God and human relations as well, showing obligations to God, parents, yourself and other people, the teaching of good manners, ethics and politness or ta'dib has done permanently will be the prime basis for further education in schools and communities. The whole message of Lukman covers the scope of education globally that include good faith, religious, social as well as intellectual and physical education. Not to mention Lukman al Hakim's advices through character-based.

The advantages that can be learned (found) from the story of Lukman al-Hakim in the Qur'an are advice material based on character (do not allying God, conscious in the supervision of God to always do good deeds, do prayer, doing what is right and what is wrong, be patient against the temptation, do not be turned away because of arrogant and haughty, humbled while walking and softened voice), the methods were exemplary, practice and action, attention and oversee, advise and warning, encouraging lovingly, prioritizing good manner. Then the functions and responsibilities of parents as the first and foremost educators in the style of Lukman which was showing a function to help children to reach maturity, educated patiently, wise, fair, communicative and instilled confidence. Similarly the responsibility in maintaining and rising, protect and ensure the health and happiness to excite, stimulate creativity and encourage the emergence of 
potential development. The purposes of coaching and education are to develop children potential, shaping his personality in order to reach prosperity in the world and in the hereafter, harmony between private life, social and divinity, balanced between cognitive, affective and psychomotor realized through habituation, delivered understanding that evantually will perform the pious and righteous personality.

\section{References}

Al-Attas, M. N. (1977). The Concept of Islamic Education, the keynote address delivered by Professor at the "First World Conference on Muslim Education" held in Mecca.

Arifin, M. (1991). Kapita Selekta Pendidikan Islam dan Umum [Capita Selecta Islamic Education and Public]. Jakarta: Bumi Aksara.

Al-Baidhawi, N. (2003). Anwar at-Tanzil wa Asrar at-Ta'wil. Beirut: Dar al-Fikr.

Barsihannur. (2009). Belajar dari Lukman al-Hakim [Learning from Lukman al-Hakim]. Jogjakarta: Kota Kembang.

Daradjat, Z. et al. (1995). Metodik Khusus Pengajaran Agama Islam [Special methodical in teaching of Islam]. Jakarta: Sinar Grafika.

Daulay, H. P. (2004). Pendidikan Islam dalam Sistem Pendidikan Nasional di Indonesia [Islamic education in the National Education System of Indonesia]. Jakarta: Kencana.

Karwadi. (2008). Emosional dalam Pemikiran Pendidikan Islam: Studi Terhadap Unsur-unsur Kecerdasan Emosional dalam Pemikiran Hasan Langgulung [Emotional in Islamic Education Thought: A Study on Emotional Intelligence Elements from Hasan Langgulung perspective]. Unpublished Thesis, Islamic State University Jakarta.

Al-Maraghi, A. M. (1946). Tafsir al-Maraghi. Beirut: Dar al-Fikr.

Al-Munawar, S. A. (2005). Aktualisasi Nilai-Nilai Qur'ani Dalam Sistem Pendidikan Islam [Actualization of Qur'anic Values in Islamic Education System]. Jakarta: Ciputat Press.

Al Nahlawi, A. (1983). Usulu al Tarbiyah Islamiyyah wa Asalibiha fi al Baiti wa al Madrasati wa al Mujtama'. Bairut: Dar al Fikr al Mu'asyir Al-Nahlawi, A. (n.d). Pendidikan Islam di Rumah, Sekolah dan Masyarakat [Islamic Education at Home, School and Community]. Jakarta: Gema Insani Press.

Al-Nahlawi. (1983). Usulu al Tarbiyah Islamiyyah wa Asalibiha fi al Baiti wa al Madrasati wa al Mujtama'. Beirut: Dar al Fikr al Muaasir.

Salthut, K. A. (1998). Menumbuhkan Sikap Sosial, Moral dan Spiritual Anak dalam Keluarga Muslim [Fostering Social Attitudes, Moral and Spiritual Child in the Muslim Family]. Yogyakarta: Mitra Pustaka.

Al-Syaibany, O. M. (1986). Al-Uhus al-Nafsiyah wa al-Tarbiyyat li Ri'ayat al-Syabab. Cairo: Dar al-Ma'arif.

Tafsir, A. (2010). IImu Pendidikan Dalam Perspektif Islam [Education in Islamic Perspective]. Bandung: PT Remaja Rosdakarya.

Ulwan, A. N. (1981), Tarbiyah al-Aulad fi al-Islam. Beirut: Dar al- Salam.

Al-Zuhaili, W. (1991). Al-Tafsir al-Munir: fi 'Aqidah wa asy-Syari'ah wa al-Manhaj. Damascus: Dar al-Fikr. 